\title{
Kualitas Soal Penilaian Akhir Semester (PAS) Buatan Guru Mata Pelajaran Kimia Kelas XI MIA SMA Di Kabupaten Kotawaringin Barat Pada Semester Ganjil Tahun Ajaran 2018/2019
}

\author{
Yesi Gasela*, Suandi Sidauruk, Abdul Hadjranul Fatah \\ Program Studi Pendidikan Kimia, FKIP, Universitas Palangka Raya, Indonesia \\ Email:yesigasela05@gmail.com
}

Diterima: 2 Maret 2020; Disetujui: 14 Maret 2020; Diterbitkan: 17 Maret 2020

\begin{abstract}
ABSTRAK
Soal yang digunakan pada Penilaian Akhir Semester (PAS) merupakan soal-soal buatan guru. Penelitian ini bertujuan untuk mengetahui dan mendeskripsikan tingkat Kualitas Soal Penilaian Akhir Semester (PAS) Buatan Guru Mata Pelajaran Kimia Kelas XI MIA SMA di Kabupaten Kotawaringin Barat Pada Semester Ganjil Tahun Ajaran 2018/2019. Penelitian ini termasuk penelitian deskriptif. Objek dalam penelitian ini adalah soal buatan guru dan jawaban siswa hasil Penilaian Akhir Semester (PAS) mata pelajaran Kimia kelas XI MIA SMA A, kelas XI MIA SMA B, kelas XI MIA SMA C, dan Kelas XI MIA SMA D, pada semester ganjil tahun ajaran 2018/2019. Teknik pengumpulan data penelitian ini adalah metode dokumentasi. Analisis data dilakukan secara logical review dan empirical review. Hasil penelitian menunjukkan bahwa hasil analisis logical review diperoleh tingkat kesesuaian soal dengan kompetensi dasar tergolong baik dengan persentase sebesar 86,67\%. Ditinjau dari aspek materi, konstruksi, dan bahasa tingkat kesesuaian soal baik dengan persentase sebesar 85,63\%. Distribusi jenjang ranah kognitif taksonomi Bloom adalah $\mathrm{C} 1$ sebesar 22,67\%, C2 sebesar 43,33\%, C3 sebesar 34\%, C4 sebesar 0\%, C5 sebesar 0\%, dan C6 sebesar 0\%. Kualitas soal PAS kimia kelas XI MIA buatan guru ditinjau dari empirical review diperoleh berdasarkan indeks daya beda, indeks kesukaran dan efektivitas distraktor. Secara empirical review, jumlah soal dengan kualitas sangat baik terdapat $35(23,33 \%)$ soal, soal dengan kualitas baik terdapat 55 $(36,67 \%)$ soal, soal dengan kualitas tidak baik terdapat 57 (38\%) soal, dan soal dengan kualitas sangat tidak baik terdapat $3(2 \%)$ soal.
\end{abstract}

Kata Kunci : daya beda, efektivitas distraktor, kualitas soal, reliabilitas, tingkat kesukaran,.

\section{PENDAHULUAN}

Pendidikan Nasional berfungsi mengembangkan kemampuan dan membentuk watak serta peradaban bangsa yang bermartabat dalam rangka mencerdaskan kehidupan bangsa, bertujuan untuk berkembangnya potensi peserta didik agar menjadi manusia yang beriman dan bertakwa kepada Tuhan Yang Maha Esa, berakhlak mulia, sehat, berilmu, cakap, kreatif, mandiri dan menjadi warga negara yang demokratis serta bertanggung jawab. Hal ini diamanatkan di dalam Undang-Undang Republik Indonesia Nomor 20 Tahun 2003 tentang Sistem Pendidikan Nasional. 
Mansyur dkk (2015) menyatakan bahwa penilaian merupakan komponen penting dalam penyelenggaraan pendidikan. Upaya meningkatkan kualitas pendidikan dapat ditempuh melalui peningkatan kualitas pembelajaran dan kualitas sistem penilaiannya. Keduanya saling terkait, sistem pembelajaran yang baik akan menghasilkan kualitas belajar yang baik. Kualitas pembelajaran ini dapat dilihat dari hasil penilaiannya. Selanjutnya sistem penilaian yang baik akan mendorong pendidik untuk menentukan strategi mengajar yang baik dalam memotivasi peserta didik untuk belajar yang lebih baik. Oleh karena itu, dalam upaya peningkatan kualitas pendidikan diperlukan perbaikan sistem penilaian yang diterapkan agar amanat Undang-Undang Republik Indonesia Nomor 20 Tahun 2003 tentang Sistem Pendidikan Nasional dapat terwujud.

Berkaitan dengan upaya peningkatan kualitas pendidikan, Sudjana (2014) mengungkapkan bahwa salah satu upaya dalam meningkatkan kualitas proses dan hasil belajar sebagai bagian dari peningkatan kualitas pendidikan dapat dilakukan melalui sistem penilaian. Dalam penilaian proses dan hasil belajar siswa di sekolah, aspek-aspek yang berkenaan dengan pemilihan alat penilaian, penyusunan soal, pengolahan dan interpretasi data hasil penilaian, analisis butir soal untuk memperoleh kualitas soal yang memadai, serta pemanfaatan data hasil penilaian sangat berpengaruh terhadap kualitas lulusan.

Berkaitan dengan pernyataan tersebut, Pemerintah Repuplik Indonesia telah menetapkan Standar Penilaian Pendidikan didalam Standar Nasional Pendidikan. Peraturan Pemerintah No. 19 Tahun 2005 Pasal 63 ayat 1 menyatakan penilaian pendidikan pada jenjang pendidikan dasar dan menengah terdiri atas penilaian hasil belajar oleh pendidik; penilaian hasil belajar oleh satuan pendidikan; dan penilaian hasil belajar oleh Pemerintah. Pasal 64 ayat 1 (hasil perubahan pertama) menyatakan penilaian hasil belajar oleh pendidik dilakukan secara berkesinambungan untuk memantau proses, kemajuan belajar, dan perbaikan hasil belajar Peserta Didik.

Mengingat Peraturan Pemerintah tersebut, ditetapkan Permendikbud Republik Indonesia Nomor 53 Tahun 2015 tentang Penilaian Hasil Belajar Oleh Pendidik dan Satuan Pendidikan pada Pendidikan Dasar dan Pendidikan Menengah, yang menjelaskan pada Pasal 1 bagian (1) bahwa yang dimaksud dengan penilaian hasil belajar oleh pendidik adalah proses pengumpulan informasi/data tentang capaian pembelajaran peserta didik dalam aspek sikap, aspek pengetahuan, dan aspek keterampilan yang dilakukan untuk memantau proses, kemajuan belajar, dan perbaikan hasil belajar melalui penugasan dan evaluasi belajar. Pasal 1 bagian (4) Penilaian Akhir adalah kegiatan yang dilakukan untuk mengukur pencapaian kompetensi peserta didik pada akhir semester dan/atau akhir tahun. Pasal 9 bagian (d) Penilaian Akhir meliputi Penilaian Akhir Semester dan Penilaian Akhir Tahun.

Berdasarkan hal tersebut, selain sebagai pedidik, guru juga merupakan penilai sebagaimana yang dinyatakan oleh Widoyoko (2016) diantara tugas guru dalam kegiatan pembelajaran adalah merencanakan kegiatan pembelajaran, melaksanakan pembelajaran dan menilai hasil belajar. Kemampuan guru dalam memilih dan menyusun instrumen penilaian yang sesuai dengan tujuan penilaian, mengolah dan menafsirkan hasil penilaian akan sangat berpengaruh terhadap kualitas data hasil penilaian sebagai dasar pengambilan keputusan. Oleh karena 
itu, kemampuan menilai proses dan hasil belajar siswa merupakan salah satu kompetensi yang harus dikuasai seorang guru maupun calon guru.

Guru dalam melakukan penilaian dan evaluasi hasil belajar peserta didik membutuhkan instrumen penilaian yang valid dan reliabel agar dapat mengukur dengan baik tingkat pencapaian kompetensi peserta didik. Untuk memperoleh instrumen penilaian yang valid dan reliabel maka guru harus melakukan analisis butir soal yang bertujuan untuk mengkaji dan menelaah setiap butir soal agar diperoleh soal yang bermutu sebelum soal digunakan. Soal yang bermutu jika digunakan dalam penilaian dan evaluasi hasil belajar akan memberikan informasi yang tepat sesuai dengan tujuannya misal, mampu membedakan peserta didik yang sudah atau belum kompeten. Analisis butir soal mencakup analisis kualitatif (validitas isi dan konstruk) dan analisis kuantitatif (tingkat kesukaran, daya pembeda, validitas, dan reliabilitas soal) (Direktorat Pembinaan SMA, 2010).

Informasi yang diperoleh dari seperangkat tes sahih dan handal (hasil tes) bisa digunakan untuk memantau perkembangan mutu pendidikan. Hasil tes untuk tujuan ini harus baik, yaitu memiliki kesalahan pengukuran yang sekecil mungkin. Kesalahan pengukuran dapat disebabkan oleh kesalahan dalam menentukan sampel isi tes, variasi emosi seseorang, termasuk variasi emosi pemeriksa lembar jawaban jika lembar jawaban tes diperiksa secara manual, dapat juga disebabkan karena soal tes terlalu mudah atau terlalu sukar (Mansyur dkk).

Hasil Observasi salah satu soal Penilaian Akhir Semester (PAS) mata pelajaran kimia kelas XI MIA Semester Ganjil Tahun Ajaran 2017/2018 SMAN 3 Pangkalan Bun Kabupaten Kotawaringin Barat adalah sebagai berikut:

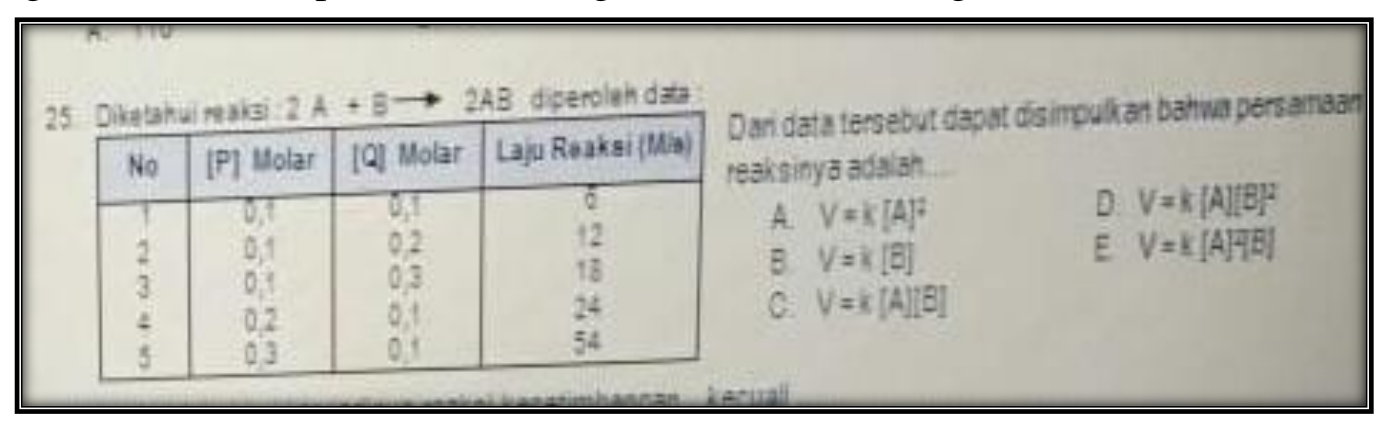

Gambar 1. Kutipan Butir Soal Nomor 25

Soal nomor 25 adalah salah satu soal dengan topik laju reaksi. Soal tersebut termasuk tingkatan C3 (menerapkan) dalam Taksonomi Bloom, soal meminta siswa agar menentukan persamaan laju reaksi, dimana sebelum menentukan persamaan laju siswa terlebih dahulu harus menentukan orde masingmasing komponen pereaksi. Jawaban yang benar dari soal tersebut adalah $\mathrm{E}$ dimana A memiliki orde 2 dan B memiliki orde 1. Jika diamati, soal tersebut adalah soal yang tidak bisa dikerjakan, karena pokok soal mengandung data yang tidak jelas yaitu data yang tidak diperlukan yang dapat diamati dari penyajian data berupa persamaan reaksi dan tabel hubungan konsentrasi pereaksi dengan laju reaksi yang ternyata tidak berhubungan. Pada persamaan reaksi diketahui reaksi tidak setara $2 \mathrm{~A}+\mathrm{B} \rightarrow 2 \mathrm{AB}$, dari persamaan reaksi tersebut dapat diketahui bahwa pereaksi yang ada adalah A dan B. Selanjutnya data yang disajikan adalah tabel hubungan konsentrasi pereaksi dan laju reaksi, namun pada tabel ini bukan konsentrasi A dan B yang diketahui melainkan konsentrasi P dan Q. Secara 
logical review soal tersebut dapat dikatakan tidak valid karena pokok soal tidak memberikan pernyataan yang diperlukan, data yang diberikan tidak sesuai dengan tujuan soal. Hal ini kemungkinan disebabkan oleh ketelitian guru yang kurang pada saat pembuatan soal.

Sebelum melakukan observasi, peneliti melakukan wawancara via pesan whatsapp terhadap guru di beberapa SMA Negeri di Kabupaten Kotawaringin Barat. Hasilnya dari 5 guru mata pelajaran kimia di sekolah yang berbeda menyatakan bahwa soal Penilaian Akhir Semester (PAS) biasanya dibuat oleh guru mata pelajaran tanpa melalui proses analisis butir soal terlebih dahulu. Soal PAS dibuat menjelang pelaksanaan PAS sehingga guru terkesan terburu-buru dalam membuat soal PAS tersebut, sehingga tidak memungkinkan guru untuk melakukan analisis soal yang telah dibuat tersebut. Akibatnya, dapat diduga bahwa akan banyak terjadi kesalahan dalam pembuatan instrumen penilaian tersebut seperti yang terjadi pada salah satu soal yang telah diobservasi peneliti. Berdasarkan kenyataan tersebut maka juga penting dilakukan analisis kualitas butir soal Penilaian Akhir Semester (PAS) yang digunakan oleh guru di Kabupaten Kotawaringin Barat agar dapat diketahui bagaimana kualitas alat ukur yang selama ini digunakan. Penelitian tentang kualitas soal buatan guru telah dilakukan oleh Salvina (2019) di Kabupaten Kotawaringin Timur.

Uraian di atas menjadi alasan peneliti untuk melakukan penelitian mengenai "Kualitas Soal Penilaian Akhir Semester (PAS) Buatan Guru Mata Pelajaran Kimia Kelas XI MIA SMA di Kabupaten Kotawaringin Barat pada Semester Ganjil Tahun Ajaran 2018/2019”.

\section{METODE PENELITIAN}

Penelitian ini tergolong penelitian deskriptif. Penelitian deskriptif, (descriptive research) adalah penelitian yang dilakukan untuk menggambarkan atau menjelaskan secara sistematis, faktual, dan akurat mengenai fakta dan sifat populasi tertentu, dengan kata lain pada penelitian deskriptif, peneliti hendak menggambarkan suatu gejala (fenomena), atau sifat tertentu; tidak untuk mencari atau menerangkan keterkaitan antar variabel. Penelitian deskriptif hanya melukiskan atau menggambarkan apa adanya (Sanjaya, 2013).

Melalui penelitian ini peneliti berusaha untuk memecahkan masalah sesuai dengan tujuan penelitian ini, maka peneliti mendeskripsikan kualitas soal Penilaian Akhir Semester (PAS) buatan guru mata pelajaran kimia SMA di Kabupaten Kotawaringin Barat kelas XI MIA pada semester ganjil tahun ajaran 2018/2019.

Penelitian ini dilaksanakan di SMA Negeri yang berada di Kabupaten Kotawaringin Barat yaitu SMAN 1 Pangkalan Banteng, SMAN 1 Pangkalan Lada, SMAN 1 Pangkalan Bun, dan SMAN 3 PAngkalan Bun. Waktu penelitian ini dilakukan sejak Januari 2019 yang merupakan waktu pengambilan data dan akan dilanjutkan dengan analisis data jika semua data telah terkumpul.

Objek penelitian ini adalah soal buatan guru yang berbentuk pilihan ganda dan jawaban siswa pada Penilaian Akhir Semester (PAS) mata pelajaran kimia kelas XI MIA SMA di Kabupaten Kotawaringin Barat pada semester ganjil tahun ajaran 2018/2019. Asumsi penelitian ini yaitu soal Penilaian Akhir Semester (PAS) mata pelajaran kimia kelas XI buatan guru SMA di Kabupaten Kotawaringin Barat adalah tes non standar yang disusun berdasarkan bahan dan 
tujuan khusus yang dirumuskan oleh para guru serta belum pernah dianalisis kualitasnya baik secara logical review maupun empirical review. Data hasil Penilaian Akhir Semester (PAS) adalah data yang sesungguhnya (hasil tes peserta didik di kelas dan mata pelajaran yang dikelola guru kimia di sekolah tempat penelitian).

Pengumpulan data pada penelitian ini menggunakan metode dokumentasi. Metode dokumentasi yaitu mencari data mengenai hal-hal atau variabel yang berupa catatan, transkrip, buku, surat kabar, majalah, prasasti, notulen rapat, legger, agenda, dan sebagainya (Winarno, 2013). Data yang dikumpulkan pada penelitian ini berupa data sekunder. Data sekunder merupakan sumber data penelitian yang diperoleh peneliti melalui media perantara, data sekunder umumnya berupa bukti, catatan atau laporan historis yang telah tersusun dalam arsip.

Tabel 1. Teknik Pengumpulan Data

\begin{tabular}{|c|c|c|c|}
\hline No. & Jenis Data & $\begin{array}{c}\text { Teknik } \\
\text { Pengumpulan Data }\end{array}$ & Analisis \\
\hline 1. & $\begin{array}{l}\text { Perangkat soal } \\
\text { (soal, indikator } \\
\text { dan kunci } \\
\text { jawaban) }\end{array}$ & Metode dokumentasi & $\begin{array}{l}\text { Butir soal dianalisis secara } \\
\text { logical review dengan penilaian } \\
\text { oleh rater mengenai kesesuaian } \\
\text { kompetensi dasar, materi, } \\
\text { konstruksi, bahasa dan kunci } \\
\text { jawaban. }\end{array}$ \\
\hline 2 & $\begin{array}{l}\text { Jawaban siswa } \\
\text { (Lembar jawaban } \\
\text { siswa) }\end{array}$ & Metode dokumentasi & $\begin{array}{l}\text { Lembar jawaban diperiksa } \\
\text { berdasarkan kuci jawaban lalu } \\
\text { diskor dan dilakukan analisis } \\
\text { empirical review yang meliputi } \\
\text { tingkat kesukaran, daya beda, } \\
\text { reliabilitas dan efektifitas } \\
\text { distraktor. Analisis } \\
\text { menggunakan aplikasi SPSS } \\
\text { versi } 25 \text { dan Microsoft Excell } \\
2010 \text {. }\end{array}$ \\
\hline
\end{tabular}

\section{HASIL PENELITIAN DAN PEMBAHASAN}

\section{Analisis Logical Review}

Sebelum penyusunan kisi-kisi soal, hal yang harus dilakukan adalah menentukan kompetensi dasar (KD) terlebih dahulu. Pada kesesuaian dengan aspek materi sebelumnya, hal yang juga harus diperhatikan adalah kesesuaian soal dengan indikator. Namun, seluruh guru kimia di SMA tempat pelaksanaan penilaian tidak ada yang membuat kisi-kisi soal termasuk indikator soal terlebih dahulu, guru hanya langsung membuat soal sesuai dengan materi yang telah dipelajari pada semester ganjil tahun ajaran 2018/2019. Oleh karena itu, tingkat kesesuaian soal dengan kompetensi dasar juga diperlukan untuk mengukur sejauh mana pembelajaran telah terlaksana pada semester tersebut, dan apakah sudah sesuai dan mewakili isi silabus/ kurikulum yang berlaku. 
Hasil penelitian menunjukkan terdapat 129 (86\%) soal yang sesuai dengan kompetensi dasar. Pada salah satu SMA tempat penelitian terdapat kompetensi dasar yang bukan merupakan kompetensi dasar pada kelas XI MIA SMA semester ganjil. Sekolah tersebut adalah SMA A (SMAN 1 Pangkalan Banteng). SMA A menampilkan 11 pokok bahasan yang merupakan campuran dari kelas X semester 1 dan 2 serta kelas XI semester 1. Guru pengampu mata pelajaran kimia di sekolah tersebut menjelaskan bahwa sekolah A telah menerapkan kurikulum 2013. Namun ketika didapati soal yang bukan merupakan pokok bahasan kelas XI semester ganjil pada kurikulum 2013, guru tersebut menjelaskan bahwa sudah kebijakan dari sekolah bahwa harus memunculkan soal-soal yang berasal dari kelas atau tingkatan yang lebih rendah.

Kaidah penulisan butir soal salah mengatur atau memberi rambu-rambu tentang bagaimana penyusunan, salah satunya adalah soal pilihan ganda, yang meliputi aspek materi, konstruksi, dan bahasa. Analisis kesesuaian butir soal dengan aspek materi, konstruksi, dan bahasa adalah salah satu cara untuk mengetahui kesahihan/ kehandalan soal. Soal yang sahih dan handal harus dirumuskan melalui penyususnan kisi-kisi dan kaidah penulisan butir soal. Hal tersebut merupakan salah satu cara untuk mengetahui keakuratan penilaian, karena ketepatan materi yang diujikan dan keterbacaan soal adalah kunci dari keakuratan hasil penilaian.

Secara umum, tingkat kesesuaian untuk aspek materi dan konstruksi tergolong tinggi bahkan sangat tinggi sehingga masing-masing aspek yang dinilai ada yang tekategori baik dan sangat baik. Untuk aspek bahasa, ternyata tingkat kesesuaiannya sangat rendah pada tiap-tiap SMA yang mengakibatkan rata-rata kesesuaian keseluruhan soal dengan aspek bahasa juga rendah dan memiliki kategori kurang baik. Hal tersebut utamanya diakibatkan oleh penulisan butir soal yang tidak sesuai EYD. Hampir $90 \%$ penulisan butir soal dari keseluruhan soal yang dianalisis tidak sesuai dengan EYD untuk aspek bahasa.

Ranah kognitif berhubungan erat dengan kemampuan berpikir, termasuk kemampuan menghafal, memahami, mengaplikasi, menganalisis, menyintesis, dan kemampuan mengevaluasi. Hasil analisis menunjukkan bahwa pada seluruh sekolah, tingkatan berpikir tertinggi pada soal adalah C3 (mengaplikasi). Kebanyakan soal-soal adalah soal dengan tingkatan berpikir C1 (menghafal) dan C2 (memahami).

Walaupun tingkat pemahaman siswa dan keterampilan guru yang masih terbatas, diharapkan paling tidak terdapat satu atau dua soal dengan tingkat berfikir tinggi. Pada SMA A soal-soal didominasi oleh soal-soal dengan tingkatan berpikir $\mathrm{C} 2$ dan $\mathrm{C} 3$, dengan persentase masing-masing $45 \%$ dan 37,5\%. Pada SMA B soal-soal didominasi oleh oleh soal-soal C1 dan C2, dengan persentase masing-masing $40 \%$ dan 51\%. Pada SMA C soal-soal didominasi oleh soal-soal C3, persentasenya mencapai $47,5 \%$, hal ini karena SMA C memperbanyak soalsoal dari materi termokimia, laju reaksi, dan kesetimbangan kimia yang hampir semua berupa soal-soal hitungan yang menerapkan rumus. Pada SMA D soal-soal juga didominasi dengan soal-soal $\mathrm{C} 2$ dan $\mathrm{C} 3$, dengan persentase masing-masing $42,28 \%$ dan $40 \%$. Belum ditemukan soal-soal berpikir tingkat tinggi pada seluruh soal yang diteliti. Hal tersebut disebabkan soal-soal yang digunakan guru diambil dari buku cetak dan kumpulan bank soal-soal ujian. Namun, guru masih belum memperhatikan kualitas soal pilihan ganda yang diambil dari sumber tersebut. 
Soal penilaian akhir semester yang diberikan kepada siswa lebih cenderung hanya menguji aspek ingatan $(\mathrm{C} 1)$, pemahaman $(\mathrm{C} 2)$, dan penerapan $(\mathrm{C} 3)$. Banyak buku yang menyajikan materi dengan mengajak siswa aktif, sajian konsep sistematis, tetapi sering di akhiri dengan soal yang kurang melatih keterampilan berpikir siswa. Sangat penting bagi guru untuk memperhatikan juga aspek ranah kognitif yang diterapkan dalam pembuatan soal-soal penilaian akhir semester, karena apabila semua tingkatan ranah kognitif diterapkan secara merata dan terus menerus, maka hasil penilaian akan lebih baik.

\section{Analisis Empirical Review}

Selain kesesuaian isi soal, soal yang bermutu juga harus memiliki reliabilitas yang baik. Hasil penelitian menunjukkan reliabilitas rata-rata soal-soal penilaian akhir semester kimia SMA di Kabupaten Kotawaringin Barat adalah 0,625 dengan kategori cukup. Artinya tingkat kejegan hasil penilaian dapat dikatakan cukup baik.

Analisis efektifitas distraktor menunjukkan hasil SMA A memiliki 7 (4,7\%) soal yang memiliki distraktor belum efektif, SMA B memiliki $16(10,7 \%)$ soal yang memiliki distraktor belum efektif, SMA C memiliki $7(4,7 \%)$ soal yang memiliki distraktor belum efektif, dan SMA D memiliki $3(2 \%)$ soal yang memiliki distraktor belum efektif. SMA B merupakan SMA dengan soal yang memiliki distraktor belum efektif paling banyak, sedangkan SMA D merupakan SMA dengan soal yang memiliki distraktor belum efektif paling sedikit. Efektifitas distraktor dari keseluruhan soal tergolong baik dan berfungsi. terdapat kurang dari 5\% soal dengan distraktor yang belum efektif pada masing-masing SMA kecuali pada SMA B yang mencapai $10,70 \%$ soal dengan distraktor belum efektif.

Soal yang baik adalah soal yang tidak terlalu sukar dan tidak terlalu mudah. Soal dikatakan sukar apabila memiliki indeks tingkat kesukaran $<0,30$, soal dikatakan sedang apabila memiliki indeks tingkat kesukaran $0,30 \leq \mathrm{TK} \leq 0,70$, sedangkan soal dikatakan sukar apabila memiliki indeks tingkat kesukaran $0,70<$ TK $<1,00$. Persentase tingkat kesukaran soal PAS kimia SMA kelas XI MIA di Kabupaten Kotawaringin Barat pada semester ganjil tahun ajaran 2018/2019 yaitu, dari 150 soal terdapat sebanyak $18(12 \%)$ soal dengan kategori mudah, 63(42\%) soal dengan kategori sedang, dan 69(46\%) dengan kategori sukar. Berdasarkan data tersebut dapat disimpulkan bahwa soal PAS didominasi oleh soal-soal sukar.

Daya beda butir tes adalah kemampuan butir tes untuk mengetahui seberapa besar suatu butir tes dapat membedakan (diskriminasi) antara peserta tes yang berkemampuan tinggi dengan peserta tes yang berkemampuan rendah. Soal diterima baik apabila memiliki indeks daya beda dengan rentang $0,40 \leq \mathrm{DB} \leq$ 1,00. Soal direvisi/kurang baik apabila memiliki indeks daya beda dengan rentang $0,20 \leq \mathrm{DB} \leq 0,39$. Sedangkan soal dibuang/jelek apabila memiliki indeks daya beda dengan rentang $\mathrm{DB} \leq 0,19$. Daya Beda Soal secara keseluruhan, soal yang diterima baik terdapat $41(27,33 \%)$ soal, terdapat $48(32 \%)$ soal yang direvisi, dan $61(40,67 \%)$ soal yang ditolak.

Tingkat kesukaran berpengaruh langsung pada daya pembeda soal. Kesukaran soal dapat menyebabkan peserta tes dengan kemampuan rendah sangat kesulitan dalam menjawab soal tersebut. Kebanyakan siswa akan memberikan jawaban 
yang asal-asalan dan tanpa dipikirkan. Akibat dari hal tersebut adalah, jika jawaban asal pilih yang dilakukan peserta didik dengan kemampuan rendah tersebut benar, sedangkan jawaban siswa yang berkemampuan tinggi justru salah, maka daya beda soal akan terbalik dalam membedakan kemampuan siswa. Soal yang terlalu mudah pun akan menyebabkan daya beda soal menjadi dapat dijawab oleh siswa dari kelompok bawah. Tingkat kesukaran soal juga akan mempengaruhi keefektifan pengecoh.

Secara empirical review, soal-soal yang baik dan layak digunakan ternyata lebih banyak jumlahnya dibandingkan dengan soal-soal yang tidak baik dan tidak layak digunakan. Soal-soal dengan kualitas sangat baik adalah soal-soal yang layak digunakan dan dapat digunakan kembali sebagai alat penilaian. Hasil penelitian menunjukkan bahwa soal dengan kualitas sangat baik seluruhnya terdapat 35 soal. Soal-soal dengan kualitas baik adalah soal-soal yang layak digunakan namun perlu diperbaiki agar dapat disimpan dan digunakan kembali. Terdapat 55 soal dengan kualitas baik. Soal-soal dengan kualitas tidak baik adalah soal yang kurang layak digunakan sebagai alat penilaian, soal seperti ini sebaiknya diperbaiki kembali. Soal-soal yang sangat tidak baik adalah soal yang sama sekali tidak layak digunakan dan harus diganti, hasil analisis menunjukkan bahwa secara keseluruhan terdapat 3 soal dengan kualitas sangat tidak baik.

\section{SIMPULAN}

Kesimpulan penelitian tentang kualitas soal Penilaian Akhir Semester (PAS) buatan guru kimia kelas XI MIA SMA di Kabupaten Kotawaringin Barat pada semester ganjil tahun ajaran 2018/2019 adalah sebagai berikut:

1. Penyusunan kisi-kisi soal merupakan hal penting yang harus dilakukan dalam pembuatan butir soal yang akan digunakan sebagai alat penilaian.

2. Kesesuain Kompetensi Dasar dari soal penilaian akhir semester di Kabupaten Kotawaringin Barat tergolong tinggi, namun masih ada Kompetensi Dasar yang belum diukur dalam penilaian akhir semester pada dua sekolah (SMA B dan SMA D) dan terdapat Kompetensi Dasar yang bukan merupakan Kompetensi Dasar yang harus diukur di kelas XI semester ganjil (SMA A).

3. Kesesuaian soal dengan aspek materi dan konstruksi dari setiap SMA di Kabupaten Kotawaringin Barat pada PAS kimia semester ganjil tahun ajaran 2018/2019 tergolong sangat baik, namun kesesuaian bahasa pada seluruh sekolah tergolong kurang baik.

4. Distribusi jenjang ranah kognitif taksonomi pada soal PAS kimia semester ganjil tahun ajaran 2018/2019 di Kabupaten Kotawaringin Barat didapatkan tingkat berpikir C1 sebesar 22,67\%, C2 sebesar 43,33\%, C3 sebesar 34\%, C4 sebesar 0\%, C5 sebesar 0\%, dan C6 sebesar 0\%. Belum ditemukan soal-soal berpikir tingkat tinggi.

5. Rata-rata reliabilitas soal penilaian akhir semester di Kabupaten Kotawaringin Barat tergolong cukup dengan indeks reliabilitas 0,625.

6. Efektifitas distraktor dari keseluruhan soal tergolong baik dan berfungsi. terdapat kurang dari 5\% soal dengan distraktor yang belum efektif pada masing-masing SMA kecuali pada SMA B yang mencapai $10,70 \%$ soal dengan distraktor belum efektif.

7. Tingkat kesukaran dari keseluruhan soal yang diteliti tergolong cukup tinggi, soal yang sukar jumlahnya hampir sama dengan soal kategori sedang dan 
mudah. Terdapat $46 \%$ soal dengan kategori sukar, $42 \%$ soal dengan kategori sedang, dan $12 \%$ soal dengan kategori mudah.

8. Daya Beda Soal secara keseluruhan, soal yang diterima baik terdapat 41 $(27,33 \%)$ soal, terdapat $48(32 \%)$ soal yang direvisi, dan $61(40,67 \%)$ soal yang ditolak.

9. Secara empirical review, jumlah soal dengan kualitas sangat baik terdapat 35 $(23,33 \%)$ soal, soal dengan kualitas baik terdapat $55(36,67 \%)$ soal, soal dengan kualitas tidak baik terdapat 57 (38\%) soal, dan soal dengan kualitas sangat tidak baik terdapat $3(2 \%)$ soal.

\section{DAFTAR PUSTAKA}

Arifin, Zainal. 2014. Evaluasi Pembelajaran. Bandung: Remaja Rosdakarya. Arifin, Zainal. 2016. Evaluasi Pembelajaran. Bandung: Remaja Rosdakarya.

Arikunto, Suharsimi. 2009. Dasar-dasar Evaluasi Pendidikan (Edisi Revisi). Jakarta: Bumi Aksara.

Direktorat Pembinaan SMA. 2010. Juknis Analisis Butir Soal. Kementrian Pendidikan dan Kebudayaan.

Direktorat Pembinaan SMA. 2017. Modul Penyusunan Soal Higher Order Thinking Skill (HOTS). Kementrian Pendidikan dan Kebudayaan.

Mansyur, dkk. 2015. Asesmen Pembelajaran di Sekolah. Yogyakarta: Pustaka Pelajar.

Marlina. 2018. Kualitas Soal Penilaian Akhir Semester (PAS) Buatan Guru Mata Pelajaran Kimia Kelas X MIA di Kabupaten Kotawaringin Timur pada Semester Ganjil Tahun Ajaran 2017/2018. Skripsi Sarjana, tidak diterbitkan, Universitas Palangka Raya.

Salvina, N., Sidauruk, S. and Asi, N.B. 2019. Kualitas Soal Penilaian Akhir Semester (PAS) Buatan Guru Mata Pelajaran Kimia Kelas X SMK Jurusan Teknologi Dan Rekayasa Di Kabupaten Kotawaringin Timur Pada Semester Ganjil Tahun Ajaran 2018/2019. Jurnal Ilmiah Kanderang Tingang. 10, 1 (Jun. 2019), 46-56.

Peraturan Pemerintah. 2015. Peratutan Pemerintah Nomor 19 Tahun 2005 Tentang Standar Nasional Pendidikan. Secretariat Negara, Jakarta.

Prastoyo, Puji dan Safrida Nelly. 2017. Analisis Kualitas Soal Ujian Mata Pelajaran Biologi di SMA Negeri 3 Medan tahun Ajaran 2016/2017. Jurnal Pelita Pendidikan Vol. 5 No. 1.

Putra, Sitiatava Rizema. 2013. Desain Evaliasi Belajar Berbasis Kinerja. Jogjakarta: Diva Press.

Ratnawulan, Elis dan Rusdiana. 2015. Evaluasi Pembelajaran. Bandung: CV Pustaka Setia.

Republik Indonesia. 2003. Undang-undang Republik Indonesia Nomor 20 Tahun 2003 Tentang Sistem Pendidikan Nasional. Sekretariat Negara. Jakarta.

Republik Indonesia. 2015. Undang-undang Republik Indonesia Nomor 53 Tahun 2015 Tentang Penilaian Hasil Belajar. Sekretariat Negara. Jakarta.

Sanjaya, Wina. 2013. Penelitian Pendidikan Jenis, Metode dan Prosedur. Bandung: Kencana.

Sudaryono. 2014. Pengantar Evaluasi Pendidikan Berdasarkan: Teori Klasik dan Modern. Jakarta: Lentera Ilmu.

Sudjana, Nana. 2014. Penilaian Hasil Proses Belajar Mengajar. Bandung: Rosda. 
Sukardi, M. 2010. Evaluasi Pendidikan Prinsip dan Operasionalnya. Jakarta Timur: Bumi Aksara.

Surapranata, Sumarna. 2009. Analisis, Validitas, Reliabilitas dan Interpretasi Hasil Tes Implementasi Kurikulum 2004. Bandung: Rosda.

Susetyo, Budi. 2015. Prosedur Penyusunan \& Analisis Tes. Bandung: Refika Aditama.

Tjahjadarmawan, Elizabeth. 2018. Bernas Kimia HOTS. Yogyakarta: PaRama Ilmu.

Widoyoko, Eko Putro. 2016. Penilaian Hasil Pembelajaran. Yogyakarta: Pustaka Pelajar.

Winarno, M. E. 2013. Metodologi Penelitian dalam Pendidikan Jasmani. Malang: Universitas Negeri Malang (UM PRESS). 